\title{
VISUAL NARRATIVITY AND THE CREATION OF A TEXT WORLD - A SEMIOTIC STUDY OF SELECTED CASES OF TRANSMEDIALITY
}

Keywords: intermediality, transmediality, verbal vs. pictorial narrativity, text world, natural narratology

\begin{abstract}
The paper, from the field of broadly conceived text studies, focuses on those aspects of the visual arts that bear a storytelling potential, on analogy to verbal texts. My interest lies mainly in the field of artistic semiotics, that is in the texts marked with aesthetic qualities. The attention will go mainly to figural painting and sculpture due to their potential to show events as evolving in time. Thus, I intend to consider the manner in which narrativization as a widely recognized cognitive propensity of the human mind to impose structure upon reality and best realized in verbal storytelling is applicable to pictorial representations and how it takes part in the construction of visual possible worlds/visual text worlds. This article is thus a contribution to semiotic research in intermediality and transmediality in interart relations.
\end{abstract}

1. Introductory remarks - intermedial and transmedial relationships among artistic texts

A very natural question to ask is why should linguists and literary theorists bother with studying the fine arts. The reasons are several. First, we communicate not by means of words or sentences, but by means of texts. Indeed, we are caught not only in the web of our native languages but also we are imprisoned in the growing web of texts. Second, texts are very different - verbal, non-verbal and mixed. This broad semiotic approach to text as a widespread cultural phenomenon, executed in the 
contemporary semiosphere in an innumerable number of ever new ways, is of necessity interdisciplinary. Third, our times are marked by the visual turn.

The best summary in support of a comprehensive science of texts as cutting across various modes, media and modalities through which they are realized is the following quote from Lars Elleström (2014: 1):

I argue that basic research in the area of media transformation - the transfer of media characteristics among media - is vital for further progress in understanding communication in general. [...] the aim of this study is to fuse a number of study areas that have been unduly separated into one overarching field of media transformation research.

The media transformation manifests itself through two related phenomena, namely intermediality and transmediality. My approach below will treat the latter as a subtype of the former, albeit this is not necessarily a unanimously approved solution. In order to understand the nature of both concepts, we need to introduce three basic definitions of key notions involved in intermedial research, all of which are applied rather inconsistently in the vast literature on the subject. I propose the following usage of these terms:

I Medium can refer to three related phenomena:

1. artistic medium/art form: literature, painting, sculpture, installation, architecture, music, dance, theatre, film, opera, ballet, performance, photography, etc.; theatre, film, opera are composite media;

2. technical support/carrier (paper, cardboard, canvas, wood, stone, metal, gypsum, light, screen); technique of execution (watercolour, tempera, oil, pencil, crayon, print - e.g. wood engraving);

3. a means of communication/channel of transmission (verbal - written or spoken; the press, radio, TV, Internet, etc.).

II Mode (often called medium as well, cf. Wolf 2005) denotes a semiotic code/system, a language, for instance a verbal/natural language realized as speech or writing; image (pictorial sign) that can be two- or three-dimensional; moving image; sound; dance; architectonic structure; urban, interior, garden design; computer games; gestures, etc.

III Modality, in turn, is best understood as a platform of delivery in terms of a specific sensory perception: visual (sight), aural/acoustic (sound), tactile/haptic (touch), olfactory (smell), gustatory (taste), kinaesthetic (movement), spatial, temporal, etc.

In the light of the above definitions intermediality can be seen as any transgression of boundaries between media/modes; the term originated in literary criticism and refers mostly to heteromedial relations between semiotic complexes but takes also homomedial relations into consideration. According to Elleström (2014: 3), intermediality so broadly understood refers to all types of relations among different media. In more traditional parlance interart relations are sometimes isolated to describe 
a subtype of intermediality related to high art, with the exclusion of non-artistic artefacts, new media, some performances, etc.

In what follows, I present a subdivision of intermedial relations, mostly following Werner Wolf's taxonomy but informed by Elleström's proposals in some places. Elleström's taxonomy, very detailed and intricate, would require a lengthy explanation, for which we have no space in this article, hence the option of using a simpler classification forwarded by Wolf.

Thus, intermediality is realized in two basic subtypes:

I Intracompositional/intramedial relationships (within one semiotic system or one work):

1. Homomedial/monomedial relations (within one semiotic system, connecting various works):

a. intertextuality proper, i.e. among verbal texts;

b. adaptations, e.g. a transposition of a novel into a drama as a literary genre;

c. translations (interlingual).

2. Heteromedial/plurimedial/multimodal relations (connecting various semiotic systems within one work), e.g. an illustrated book, comic strips, an audiobook, a song with lyrics, an operatic work, a piece of architecture with paintings and sculptures, etc.; all of them are medial mixtures/hybrids.

II Extracompositional/extramedial relationships (between various works and/or media):

1. Adaptation - e.g. a filmic or theatrical adaptation of a novel, a drama changed into an opera, a verbal fiction changed into comics (Jakobsonian intersemiotic translation, and a clear case of what Elleström dubs transmediation/remediation/intermedial transposition, that is a transfer of media characteristics from one medium/mode to another, accompanied by transformation of media characteristics);

2. Transmediality (intermedial reference/remediation according to Elleström) covers phenomena non-specific to individual media but occurring across them in an independent way. These are: motifs, themes, archetypes, thematic variants, figuration, and narrativity, which all can be found in the texts of literature, opera, theatre, ballet, film, the visual arts, music. The term transmediality in this sense comes from Irina O. Rajewsky (2002, 2005).

In turn, transmedial in Elleström's work refers to all intermedial relations characterized by transfers so it is much broader than the definition I have assumed above after Wolf and which excludes transfer of characteristics from a source to a target text. Transmediality in this broad sense can also appear in the form called intermedial imitation by Elleström, to wit literarization of music, musicalization of literature (Wolf 1999), musicalization of painting or architecture, filmicization of novels or paintings, etc.

3. Ekphrasis - traditionally a poetic description of artworks, mostly paintings, sculptures, buildings or gardens, thus "the verbal representation of a visual 
representation" (Heffernan 1993: 3), with time extended to include verbal descriptions of musical compositions, and finally expanded by Siglind Bruhn (2000) to cover a "representation in one medium of a text composed in another medium", whether real or imagined (cf. Elleström 2014: 33, who also refers to ekphrasis as intermedial imitation).

In the sections to follow our attention will be limited to transmediality in the narrow Wolfian meaning and specifically to one particular feature of it - narrativity - as inherently present (without transfer) in various media and modes. Our task is to see how narration, typically associated with verbal texts, can find its realization in pictorial and sculptural representations.

\section{Storification, text worlds and narration units}

A cognitive import of structuring the happenings in the world around us in terms of a story (with fabula as its chronological structure and plot as a specific, more often than not non-chronological sequence of events) has been widely recognized in contemporary research. It is worth quoting the definition of narrative drawn from Michael Toolan's (2001: 8) eponymous study:

A narrative is a perceived sequence of non-randomly connected events, typically involving, as the experiencing agonist, humans or quasi-humans, or other sentient beings, from whose experience we humans can 'learn'.

I find this description valuable not only for pointing to the educational value of narration, but above all by mentioning the fact that stories transport us from actuality into a storyworld, a fictitious alternative reality. Hence, narration, almost automatically, participates in the (re)construction of a possible world/text world: "A fabula is a possible world", says Umberto Eco (1979/1994: 226). ${ }^{1}$ Such world supports an artwork that strives to render temporality and causality in its own unique medium, in addition to presenting a set of individuals and their relationships. By definition, a possible world should consist of possible individuals and the configurations in which they appear. But this is not enough - it is tacitly assumed that possible/text worlds should possess a minimal history, i.e. they should represent states of affairs as evolving in time.

The degree of storification/emplotment (White 1987), or in cognitive parlance the imposition of the SOURCE-PATH-GOAL pattern on scenarios (Johnson 1987; Lakoff 1987), related also to the phenomenon of tellability (significance and newsworthiness of the story matter, cf. Labov 1972; Bruner 1991; Fludernik's [1996, 2003]

Different terms are used to refer to alternative universes created by artistic texts: possible worlds, text/discourse worlds, storyworlds, virtual worlds, etc. For our purposes the technical differences between them are irrelevant. 
notion of experientality; ${ }^{2}$ Sonesson $1997^{3}$ ), postulated originally for verbal texts and extrapolated onto visual narratives, will differ according to the genre of representation and the narration unit it exemplifies. Hence, I propose to subdivide pictorial narrative units roughly into: 1) narrative images, 2) narrative sequences (backed up by small worlds/mini-worlds/subworlds) and 3) full-blown narrations (backed up by extended textual worlds).

Assuming that transmediality includes, apart from all the elements listed in Section 1, also the existence of story/possible/text worlds in its inventory, it can be claimed that visual worlds come into being at level 2) of narrative sequences. From the narrative point of view the most controversial level 1), on analogy to non-epic poetry, is supported by scenes/scenarios rather than worlds proper. Narration culminates in 3) full-blown worlds, present in rich pictorial cycles, e.g. Marc Chagall's oeuvre that creates its own unique universe with subworlds (Chrzanowska-Kluczewska 2016) owing to a consistent use of the same possible individuals, states of affairs, symbols, etc. Blaise Cendrars produced an ekphrastic poetic summary description of this hybrid, surreal and oneiric world in which reality combines with memories and fictions.

In turn, the oeuvre of Robert Devriendt (1955-), a Belgian painter of small-format works, has been likened by critics "to a single long film or TV series, in which the different individual series function as episodes or chapters" (Steverlynck in Devriendt [2015-2016] Catalogue: 15).

An additional methodological issue is whether the "natural narratology" postulated by Fludernik $(1996,2003)$ for verbal fictional texts can be extrapolated onto pictorial figural texts. In this model, "natural narrative", i.e. spontaneous conversational narrative, is taken to be "the prototype of all narrative" (Fludernik 2003: 248), thus providing a cognitive background for all genres of storytelling. An accompanying important cognitively-oriented query is whether the interpreters faced with pictorial narrativity turn to so-called naturalization scripts (proposed by Culler 1975; Fludernik 1996, 2003) that have direct recourse to human experiential (real world) patterns, related to, among other things, the interpreters' embodiment, emotionality and dependence on the environment. Naturalization scripts are the "reading" strategies particularly useful in solving textual inconsistencies and in construing more complete world stories through "establishing overarching interpretative patterns" (Fludernik 2003: 251).

2 Monika Fludernik (2003: 249) defines experientality as a "reworking of experience in terms of its emotional and evaluative significance" and takes it to be a deep-structure cognitive feature of every narrative, prior to the formulation of the fabula/plot.

3 Göran Sonesson (1997: 246), referring to previous discussions of narrativity by Didier Coste, Marie-Laure Ryan and Gerald Prince, opposes the concept of narrativehood as "the mere presence of a narrative link" to narrativity, which relates to the fact of being "a good story" (newsworthy, dynamic, shocking, etc.). 


\section{A visual narrative image - painting}

Units of visual narration, on analogy to the units suggested for verbal texts, run incrementally starting from 1) narrative images (single scenes, with the often quoted Paleolithic "hunting incident" from Lascaux as one of the earliest pieces of painted narrative, cf. Bandi et al. 1961). They epitomize what in linguistics is known as implied scenarios (Langacker 1987) and in literary theory as minimal or micro-narration (Wolf 2005; Filar 2013).

Our first study case takes us back to the dawn of the fine arts in Europe - the Franco-Cantabrian art of the Upper Paleolithic (starting ca. 30 ,ooo years ago) that contains fine examples of murals. One of the most famous scenes can be found in Lascaux, Dordogne. In one of the limestone cave galleries:

[...] one of the few narrative compositions of Ice Age art has been discovered: a badly wounded bison, its flank pierced by a lance, its horns lowered ready for a charge, and before it, sketched as always with a few strokes, the figure of a man is seen prostrate on the ground: in the foreground is a bird on a perch, and to the left a rhinoceros can be seen moving away. The whole composition is drawn in black, with the lines slightly blurred. It has been interpreted in many different ways; it is probably either a tragedy of the chase or a scene of a magic ritual character. (Bandi et al. 1961: 37)

Zbigniew Herbert (2004: 12-13) offers an excellent ekphrastic description of the Lascaux scene in his essay Barbarzyńca w ogrodzie claiming its similarity to ancient drama, with its unity of time, place and a limited number of protagonists (man, bison, bird, rhino). The import of this scene is dramatic in the double meaning of this word - Herbert underscores the fact that contrary to the rest of the FrancoCantabrian art, which is non-anecdotic, this one evokes a narration owing to the presence of a human (or half-human) being. Herbert is right - the image forces the viewer to speculate, retrospectively, what has really happened, though a prospective ${ }^{4}$ deployment of this "folded narration" (Anna Pajdzińska's term quoted in Filar 2013: 89) is also possible. To use Ingardenian terminology, what is being called for is a concretization of this painted scene in terms of a simple fabula.

\section{A narrative sequence - painting and sculpture}

Next come narrative sequences, e.g. hagiographical paintings, the Passion, Resurrection and Last Judgment scenes in the tradition of Western and Orthodox religious iconography; painted and sculpted medieval retables; in contemporary European art for instance Jerzy Duda-Gracz's Passion series “The Jasna Góra Golgotha of

4 Sonesson (1997: 247), in his analysis of "mute" narratives enclosed in several pictorial texts, invokes Husserlian notions of retention and protention in the temporal deployment of a virtual story, thus speculations about the past and the future, respectively. 
the Third Millennium" (2001) ${ }^{5}$ or Robert Devriendt's (2015-2016) synecdochically fragmented sequences of miniature oil paintings that invite the viewer to fill in the lacunae in narration in the manner close to reconstructing filmic sequences.

Narrative sequences have found the most intricate realization in the art of iconpainting (which, we should remember, according to icon-creators has been likened to writing a verbal text). A good instance of such a developed painterly narration is $15^{\text {th }}$-century icon of St Paraskeva of Tyrnovo, once in the Orthodox church at Uście Gorlickie, now in the collections of the Historical Museum in Sanok. The saint's life is shown as the cycle of 12 border scenes surrounding the central representation of the holy hermit. The scenes run in the margins and the naturalization script requires us to read them top-down, then to the right and bottom-up. The speedy narration proceeds from Paraskeva's birth, through seclusion in the desert, to her death and transfer of her corpse to the city. The fact that her body has not disintegrated proves her saintliness. In the last scene the saint is enthroned in heaven, surrounded by angels, as an object of religious cult. This biographical cycle is a vision of the individual hybrid world of earthly and heavenly existence, shown synecdochically through the most salient moments so the condition of tellability, that is newsworthiness, has been preserved.

Another instance of visual biography is the representation of Crucifixion (first half of the $17^{\text {th }}$ century), once in the Orthodox church at Lipie, now in the Historical Museum in Sanok. This rendition shows a richer subworld from the adult life of Jesus, starting with his miracles, culminating in the Passion, proceeding to Resurrection and his post-Resurrection stay on earth until Ascension. The interpretation of all the scenes (23, including the focal scene of the Crucifixion), due to their congestion, demands a certain physical and intellectual effort on the viewer's part. The reconstruction of this world will be impossible for the persons not conversant in Christian iconography. The naturalization script may impose on us a certain order of reading scenes (e.g. a commonly met anti-clockwise direction), which can prove misleading. In fact, the reading of particular scenes should proceed horizontally in six rows, then turn vertically to the central image of Crucifixion, after which it returns down to continue the horizontal reading. In the most extreme cases of large representations the number of narrative scenes surrounding the central image can reach even 124 scenes, as is the case of one of the icons in the Kremlin main Sobor in Moscow.

Marc Chagall played creatively on this visual narrative model in his well-known White Crucifixion (1938, The Art Institute of Chicago). The form of the painting resembles that of icons of the Orthodox Church. Chaotic narration takes place around the central scene with the Jewish-Christian Jesus crucified: from the Old Testament personages (the despairing prophets), to the massacres and plunderings

\footnotetext{
J. Duda-Gracz (1941-2004), Częstochowa-born, an outstanding Polish painter and illustrator, offered a cycle of 18 paintings to Our Lady sanctuary and the Paulist Monastery at Jasna Góra. The cycle, featuring severely distorted personages, full of historical and symbolic allusions, re-contextualized the narration of the Way of the Cross, situating it in a rather dreary Polish social scenery of his times and criticizing it through grotesque and turpism.
} 
perpetrated by Bolshevik hordes, to refugees in the boat, a Nazi henchman setting fire to a synagogue, to dispersed Jews saving the Torah, to Ahasverus - the Eternal Wanderer stepping over the burning scrolls. This dramatic hybrid world of the sacrum and profanum is in a large measure a reflection of the real world from the period of Stalinism and Fascism.

Let us turn to yet another case of transmedial narrativity. Kraków boasts one of the most famous Gothic sculpted altars, the work by Veit Stoss (1477-1489) in St Mary's Basilica. This main altar, in the form of a pentaptych $(11 \times 12 \mathrm{~m}$ in size, with two wings at the back), is a real piece of visual narration, exquisitely executed in lime wood. The retable is a sculpted narration of life stories of Jesus and his mother Mary, which are intertwined. While open, this "lime-wood book" features seven scenes (Annunciation, Birth of Christ, Three Magi, Resurrection, Ascension, The Coming of the Holy Ghost, and the central scene of Dormition topped by Assumption and Coronation of Mary, “to be read bottom-up”, cf. Chrzanowski 1985).

The narration is "speedy", highly selective, opening wide narrative gaps between the scenes, which should be filled in by the viewer in the process of textual concretization. The naturalization script of reading scenes anti-clockwise or horizontally has to be rejected by the garden-path tactics: the reading proceeds top-down vertically in the wings. This world finds its expansion in the scenes that complete the narration when the wings of the altar are closed.

Of special interest is the opening scene of the sculpted fabula, an instance of what can be called minimal narration, with two incidents combined, namely: Annunciation to St Joachim and the subsequent meeting of St Joachim and St Anne at the Golden Gate. In one panel two incidents have been brought together (symmetrically opposed), realizing a compressed, economic way of narration, which obviously requires a certain amount of aesthetic sensibility and attention on the part of the viewer.

\section{Intermedial narrative sequences: "condensed narratives" by Robert Devriendt - paintings like film stills}

These tiny canvases, painted in minute detail, form narrative structures ranging from 3 to 12 items. Text worlds thus created are skeletal and their reconstruction/ concretization is quite free. Their most striking feature is that they resemble photos or, rather, film stills. We can see this art either as an intermedial enterprise in which painting is being translated into the visual language of cinematography (intersemiotic translation) or playing on the fact that narration is prominently present both in the semiotic mode (code) of painting and in the semiotic mode of filmic language (here, playing transmedially only on the visual modality).

A word of caution is in place: due to their linear presentation, the paintings make the viewers inclined to read them from left to right and to see a causal relationship between them. Yet, this naturalization script may be misleading: the logical and chronological order is often elusive. As Devriendt's art has a strong cinematographic flavour (transmedial effects in the sense of filmicization of painting), it is worth 
citing Jean-Luc Godard: "A film should have a beginning, a middle and an end, but not necessarily in that order" (quoted after Steverlynck in Devriendt 2015-2016: 15). Some images reappear across various series, for instance photograph-like representations of mysterious women, whose role in the narration is equivocal. The critic Lorenzo Benedetti (in Devriendt 2014) compares Devriendt's paintings to stills from a film noir (which we could describe as photographicization of painting). What he calls the montage of contrasts, juxtaposes the ambivalent and antithetical elements of the narrative: man-woman, murderer-victim images/portraits. Certain motifs are repetitive: exploding laptops, burning cars, women's shoes and accessories, closeups of human faces or bodies, all creating what can be called metonymic situations (Benedetti) but which I - according to my own taxonomy of tropes (ChrzanowskaKluczewska 2013) - will define rather as synecdochical moments.

Narrative gaps of unspecified size are left between particular images to be filled in according to the viewer's imagination. Some critics say their rhythmical sequences possess a musical value vested in inner rhythm of repetitions. Rhythm of this type will belong to transmedial effects present - through structural reiterations realized in various modes - in music (primarily), in painting and film (secondarily), as well as in verbal language, where even prose can achieve an instrumental quality through an apt application of internal rhymes, assonance, consonance, alliteration and syntactic parallelism.

\section{Conclusion: Narrativity and visual text worlds}

The concept of storyworld/text-world, associated primarily with verbal texts, can find its extension to encompass fictional or hybrid worlds of the visual arts. Hence, a broadly (semiotically) conceived text-world may become an integrational category uniting various artistic media, such as literary creations, painting, sculpture, theatrical, operatic and filmic forms and even architectural design. The discussion on the narratively-induced world-creating potential of texts realized in various artistic media, as well as on the manner in which they are interpretable in perceptually and culturally individualized contexts in the process of concretization/actualization, should bring together phenomenological, cognitive and semiotic studies on verbal and non-verbal art criticism (cf. Ingarden 1931/1973; Sonesson 1997; Crowther 2009; Pimenta, Poovaiah 2010).

Significantly, the fact that the seeds of visual narration are already present in the Paleolithic art can be taken to corroborate Fludernik's belief in tracing the roots of all narrative to oral storytelling, before the fine arts started to rely on narrations mediated by the written texts.

In turn, the fact that some analytical tools borrowed from text/discourse studies and linguistics in general have been frequently employed in the semiotics of the visuals should by no means be taken as a symptom of "linguistic imperialism" in the study of non-verbal texts but rather as a proof of the occurrence of transmedial effects that require a common descriptive terminology. 


\section{References}

Bandi H.-G. et al. 1961. The art of the Stone Age. Forty thousand years of rock art. New York. Bruhn S. 2000. Musical ekphrasis: Composers responding to poetry and painting. Hillsdale, NY. Bruner J. 1991. The narrative construction of reality. - Critical Inquiry 18: 1-21.

Chrzanowska-Kluczewska E. 2013. Much more than metaphor. Master tropes of artistic language and imagination. Frankfurt am Main.

Chrzanowska-Kluczewska E. 2016. Światy możliwe w tekście literackim i „tekście” malarskim oraz ich niedookreślenie. Przyczynek semiotyczny do semantyki światów możliwych. Paczkowska A., Gałkowski S., Stanisz M. (eds.). Filozofia $w$ literaturze. Literatura $w$ filozofii 2. Światy możliwe. Projekty. Rzeszów: 50-69.

Chrzanowski T. 1985. Ottarz Mariacki Wita Stwosza. [Photographs by D. Sprudin]. Warszawa.

Crowther P. 2009. Phenomenology of the visual arts (even the frame). Stanford (CA).

Culler J. 1975. Structuralist poetics. Structuralism, linguistics and the study of literature. London.

Devriendt R. 2014. Broken stories. Ludion, Antwerpen.

Devriendt R. 2015-2016 = "Robert Devriendt. Making Connections" - exhibition in Kraków [with the text "Murder, she wrote" by Sam Steverlynck].

Eco U. 1979/1994. Lector in fabula. Warszawa.

Elleström L. 2014. Media transformation. The transfer of media characteristics among media. Basingstoke (UK), New York.

Filar D. 2013. Narracyjne aspekty językowego obrazu świata. Lublin.

Fludernik M. 1996. Towards a 'natural' narratology. London.

Fludernik M. 2003. Natural narratology and cognitive parameters. - Herman D. (ed.). Narrative theory and the cognitive sciences. Stanford (CA): 234-267.

Heffernan J.A.W. 1993. Museum of words: The poetics of ekphrasis from Homer to Ashbery. Chicago, London.

Herbert Z. 2004. Barbarzyńca w ogrodzie. Warszawa.

Ingarden R. 1931/1973. The literary work of art. An investigation on the borderlines of ontology, logic, and theory of literature. With an appendix on the function of language in the theatre. [Transl., with an Introduction, by G.G. Grabowicz]. Evanston.

Johnson M. 1987. The body in the mind: The bodily basis of meaning, imagination, and reason. Chicago.

Labov W. 1972. Language in the inner city. University Park (PA).

Lakoff G. 1987. Women, fire and dangerous things: What categories reveal about the mind. Chicago.

Langacker R. 1987. Foundations of Cognitive Grammar. [vol. 1: Theoretical prerequisites]. Stanford (CA).

Pimenta Sh., Poovaiah R. 2010. On defining visual narratives. - Design Thoughts 08.2010: 25-46.

Rajewsky I.O. 2002. Intermedialität. Tübingen.

Rajewsky I.O. 2005. Intermediality, intertextuality, and remediation: A literary perspective on intermediality. - Intermédialités 6: 43-64.

Sonesson G. 1997. Mute narratives: New issues in the study of pictorial texts. - Lagerroth U.-B., Lund H., Hedling E. (eds.). Interart poetics. Acts of the congress "Interart Studies: New Perspectives", Lund, May 1995. Amsterdam, Atlanta: 243-252.

Toolan M. 2001. Narrative: A critical linguistic introduction. [ $2^{\text {nd }}$ edition]. London, New York.

White H. 1987. The content of the form: Narrative discourse and historical representation. Baltimore.

Wolf W. 1999. The musicalization of fiction: A study in the theory and history of intermediality. Amsterdam, Atlanta.

Wolf W. 2005. Pictorial narrativity. - Herman D., Jahn M., Ryan M.-L. (eds.). Routledge encyclopedia of narrative theory. London, New York: 431-435. 